\title{
A favor de uma sociologia intercultural e histórica da laicidade ${ }^{1}$
}

\author{
In favor of an intercultural and historical \\ sociology of laicity
}

Jean Baubérot*

Meus trabalhos tentam, há muito tempo, elaborar uma sociologia da laicidade que relacione as diferentes laicidades enpíricas com processos de laicização. Jean-Paul Willaime (JPW) acaba de publicar um "ensaio", com uma "parcialidade assumida", que comporta uma controvérsia amigável, longa, às vezes intensa, em relação ao meu ponto de vista sobre o que ele considera como nossas "divergências de ordem sociológica" (Willaime, 2008, p. 79-103). Os temas tratados interessam à comunidade dos sociólogos, indo muito além de possíveis divergências entre dois de seus representantes. Por isso, aclarar minha abordagem, mostrar sua coerência interna ${ }^{2}$, contribui para um debate mais amplo ${ }^{3}$. Eis o propósito deste artigo, que fará referências a estudos mais desenvolvidos ${ }^{4}$, facilitando assim uma breve síntese.

Nossas "divergências de ordem sociológica" manifestam-se, segundo Willaime, em três aspectos: "no emprego do conceito de religião civil, numa interpretação da laicidade que tende a privatizar totalmente o religioso, afastando-o da esfera pública, no fato de que ele [=JB] não leva

* Historiador e sociólogo da religião e da laicidade, presidente honorário da École Pratique des Hautes Études, autor de mais de vinte obras, fundador do Groupe de Sociologie des Religions et de la Laïcité (CNRS-EPHE), coautor da Declaração Internacional da Laicidade. $<$ jeanbauberot@hotmail.com>.

1 Este texto foi publicado originalmente na Archives des Sciences Sociales des Religions, v. 54, n. 146, 2009, p. 183-199. A tradução e a publicação foram autorizadas pelo autor e pelo editor do periódico. A tradução para o português foi efetuada por Vanise Dresch.

2 Já que Willaime acredita encontrar contradições entre Baubérot 2008a e Baubérot 2006a.

3 Diante da impossibilidade de retomar todas as críticas, seleciono as que me parecem ter um alcance mais amplo.

4 Em contrapartida, para ser breve, não mencionarei os trabalhos aos quais se referem explicitamente esses estudos.

\begin{tabular}{|c|c|c|c|c|c|}
\hline Civitas & Porto Alegre & v. 11 & n. 2 & p. 284-302 & maio-ago. 2011 \\
\hline
\end{tabular}


verdadeiramente em conta o que eu [=JPW] designo como o paradigma da ultramodernidade, embora ele [=JB] reconheça, em última instância, alguns $\operatorname{traços}^{5}$ desse paradigma". Esses temas de debate, cuja formulação eu não adotarei obrigatoriamente, o levam a contestar uma de minhas obras - crítica - sobre os discursos do presidente Sarkozy (Baubérot, 2008a). A esses três aspectos, acrescentarei uma diferença de abordagem da secularização que me parece decisiva.

\section{A distinção entre secularização e laicização}

A primeira diferença de alcance geral diz respeito à adesão de JPW a uma concepção clássica da secularização, enquanto eu estabeleço uma distinção entre secularização e laicização ${ }^{6}$. Minha abordagem surgiu a partir de uma constatação: se lançarmos um olhar, ainda que pouco distanciado, sobre a tribo dos sociólogos da religião, é fascinante observar como, há meio século, ela tem julgado o emprego do termo "secularização" pouco operatório, equívoco, excessivamente multidimensional, etc., embora continue a empregá-lo muitas vezes, sem pestanejar, como referência central. Alguns ateiam fogo àquilo que adoraram, como Peter Berger, insistindo na "dessecularização" atual, o que não foge do mesmo arcabouço conceitual. Esse impasse tem se prolongado por décadas, mas, para alguns, não se deve de modo algum sair dele ${ }^{7}$ !

Em linhas gerais, a posição de JPW é a seguinte: ele admite que a distinção entre secularização e laicização "não é desprovida de interesse, principalmente porque introduz a intervenção voluntarista do político", mas, em última análise, considera mais conveniente limitar-se apenas ao termo secularização (Willaime, 2006b, p. 763 et seq.). Ora, na verdade, na abordagem clássica, a "secularização" é enfocada às vezes como paradigma teórico, às vezes como conceito. Isso já é um primeiro e grande equívoco. O segundo equívoco provém do fato de que o conceito de "secularização" é aplicado ora para indicar, seguindo a linha de Weber, uma mudança estrutural de representação do mundo (secularization), ora para indicar, na perspectiva de Durkheim, um processo de diferenciação sociopolítico e institucional (Secular State) $)^{8}$. Não é de espantar que esses múltiplos empregos gerem tantas confusões! Para encontrarmos um sistema de classificação mais operatório,

\footnotetext{
Idem, 2008, p. 114-116, 86.

6 Cf. meu estudo "Laïcité, laïcisation, sécularisation" in Dierkens, 1994; e também (entre outros), Baubérot; Mathieu, 2002; Baubérot, 2004; $2007 \mathrm{~b}$.

7 Isso é bem conhecido, o que me permite ser muito alusivo.

8 Considerações parciais: análises weberianas (modos de dominação, definição do poder...) também são indispensáveis no emprego da noção de "laicização".
} 
basta não nos privarmos de empregar - problematizando-os - vários termos de que dispomos.

Proponho adotar como paradigma o termo "modernidade". Uma das vantagens do emprego deste termo está em ampliar a perspectiva, em não se entrincheirar na subdisciplina da sociologia da religião9. Porém, é preciso evitar também todo e qualquer risco de narrativa mitológica da construção das sociedades modernas e, para tanto, dispor de conceitos operatórios e realizar uma periodização.

Em minha perspectiva, portanto, a palavra secularização não é empregada como paradigma, mas (somente) como um conceito ideal-típico contendo um significado preciso. Originariamente, esse termo ganhou duas acepções muito diferentes. Na Idade Média, significava o processo pelo qual um religioso abandonava a vida monástica para viver no "século" (saeculum). Quando Bento XVI deu uma "aula" universitária sobre as "origens da cultura ocidental" a setecentos intelectuais em Paris ${ }^{10}$, seu discurso teve por tema os monges como inventores, "em busca de Deus", de uma "nova cultura", a da cristandade. De seu ponto de vista, esse discurso é coerente: a cultura religiosa monástica representava então, conforme a expressão de Durkheim, a "sociedade ideal", que moldava os padrões de representação para pensar as problemáticas da "sociedade real".

A partir do século XVI, no entanto, uma nova acepção muito diferente do termo secularização foi adotada: a apropriação pelo Estado ou por uma potência laica de bens ou funções que até então pertenciam ao domínio da Igreja (Casanova, 1994, p. 12 et seq.). Essa nova acepção consagrou-se com as discussões prévias ao Tratado de Vestfália. Etapa decisiva para a paz entre as religiões, esse tratado contribuiu para a criação de um espaço autônomo em que o político e o jurídico constituíram o lugar de construção do interesse geral que a religião não conseguia mais ocupar.

Isso explica o duplo emprego, por alguns sociólogos, da família semântica do termo "secularização", numa perspectiva sociocultural de representação do mundo e noutra perspectiva sociopolítica e sociojurídica. Com exceção do famoso livro de Martin (1978), os sociólogos da secularização, em geral, dão pouca atenção ao sociopolítico e privilegiam a primeira acepção, sem obrigatoriamente se aterem a ela, o que contribui para aumentar o mal-estar teórico já assinalado. Poderíamos dar muitos exemplos, mas citemos apenas um: o "paradigma da secularização" de Bruce apresenta vinte e dois itens, sendo

\footnotetext{
9 Isso já é feito, mas não suficientemente.

${ }^{10}$ Em setembro de 2008.
} 
que um único remete ao sociopolítico (Bruce, 2002, p. 4). Em contrapartida, sociólogos do político, juristas e outros empregam a noção de Secular state ou de secularism de um modo bem diferente, derivado da segunda acepção ${ }^{11}$.

A dificuldade foi percebida por alguns sociólogos, tais como Dobbelaere, que propôs empregar então o termo "laicização". Porém, como um "velho crente da secularização"12, ele restringe a "laicização" a um papel de subcategoria da "secularização", cujo emprego permanece multidimensional. Isso gera no autor hesitações significativas quanto ao sentido e ao status dessa subcategoria da "laicização". Ela é às vezes um dos "três níveis" da secularização, às vezes uma "secularização manifesta" oposta a uma "secularização latente"13. Portanto, é o momento de praticar o agnosticismo metodológico, de dessacralizar o emprego do termo "secularização"! De um ponto de vista heurístico, é mais operatório empregar dois conceitos diferentes.

A secularização privilegia, então, as mutações socioculturais suscitadas pela dinâmica social, pela evolução dos saberes e das técnicas, pelo desenvolvimento da racionalidade instrumental. Ela é, de fato, na maioria das vezes, "latente", efeito não desejado de dinâmicas sociais que mudam as representações societais do mundo e os comportamentos da vida pública. Isso já faz dela o instrumento de medida de um vasto campo! O processo de laicização, por sua vez, concerne à regulação política, jurídica e institucional da religião, do credo, da totalidade do simbólico, com suas transações e seus conflitos explícitos ${ }^{14}$.

Micheline Milot também propôs uma distinção análoga entre as duas noções e analisou "os traços de uma laicização sem secularização" no Quebec (2002, p. 67-69). Séverine Mathieu e eu comparamos dois processos sócio-históricos: o britânico com dominante secularizadora e o francês com dominante laicizadora (2002). Willaime (2006b, p. 2), depois de Grace Davie, indaga: "a secularização é uma exceção europeia?". Mas, como mostra este número de Archives de Sciences Sociales des Religions, não existe exceção europeia em matéria de laicização (Baubérot, 2007e). Com certeza, o estudo das interferências e também das dissonâncias entre secularização e laicização contribui para a análise pertinente de temas precisos. Assim, contra a tese recente de Berger, parece-me pertinente considerar a hipótese de que as sociedades de cultura muçulmana atuais sofrem um processo de secularização

${ }_{11}$ Cf., por exemplo, Shakman, 2008.

12 É pelo menos assim que Casanova (1994, p. 11), com senso de humor, o designa.

${ }^{13}$ Cf. Dobbelaere, 1981 e 2008.

${ }^{14}$ Estas breves indicações são mais aprofundadas nos estudos mencionados na nota n. 7 . 
(Courbage, Todd, 2007) que os movimentos islamitas tentam desafiar através de uma deslaicização.

\section{Laicização, secularização e modernidade}

Secularização e laicização são instrumentos para explicar processos sócio-históricos. Convém, portanto, periodizar. De minha parte, formulei a noção de patamares de laicização, válida não somente para o caso francês (Baubérot, 2004; 2007a), mas também, com as devidas modificações, como tipo ideal, permitindo avaliar processos relativos à Europa e às duas Américas (Baubérot, 2007e) (15 $^{15}$ Essa noção de patamar inclui diferentes indicadores (o institucional, a legitimidade, o pluralismo). Antes de abordá-los de modo um pouco mais concreto, esclareço que esses patamares correspondem, esquematicamente, a três períodos-tipos da modernidade (o que também leva em conta o processo de secularização): a modernidade ascendente, a modernidade estabelecida e a modernidade tardia. Trata-se de aplicar a tipologia do paradigma da modernidade em matrizes que se sucedem, podendo também sobrepor-se em dado momento.

O primeiro patamar corresponde a um momento histórico em que a confiança na conjunção dos progressos é razoável: cresce o bem-estar. A realização do projeto das Luzes (a busca da felicidade pelo controle da Natureza e a concentração das questões sociais na "vida do presente") obtém resultados irrefutáveis, embora gere contradições (sobretudo, entre seu aspecto universalista e seu darwinismo social em que a mulher, o colonizado... são marcados pela Natureza e por suas particularidades, ao contrário do homem branco). A modernidade é ascendente.

No segundo patamar, essa modernidade estabeleceu-se, e suas contradições tornam-se perceptíveis aos poucos. As duas guerras mundiais suscitam novas representações, tais como o desdobramento de um "bom" progresso criador de vida e um "mau" progresso portador da morte, tendo este por símbolos terríveis Auschwitz e Hiroshima.

No plano do bem-estar, a versão liberal e a versão socialista opõem-se com seus grandes discursos político-ideológicos. A descolonização mostra os aspectos particularistas de um universalismo posto a priori, as revoltas estudantis contra as instituições (1968) fragilizam estas últimas, a revolução islâmica no Irã (1979) e o desmoronamento do Muro de Berlim (1989) mudam o cenário geopolítico. Tudo isso juntamente com outras mudanças sociais (costumes, globalização, etc.) suscitam novos questionamentos.

${ }_{15}$ Para a Ásia e para a África, a noção pode manter certa pertinência, mas de modo mais hipotético. 
Surge então um terceiro período-tipo da modernidade em que a ciência questiona suas próprias aplicações técnicas (inversão em relação às Luzes, em que a ciência começava a ter efeitos técnicos): as interrogações sobre o nuclear civil, a bioética, o aquecimento climático, os atentados à biodiversidade, etc. provêm de debates que se desenrolam no cerne dos saberes científicos (com instrumentalizações ideológicas). Cria-se uma desconexão entre progresso dos saberes e progresso técnico, podendo este ser posto em xeque pelo primeiro por ter efeitos contraprodutivos para o "progresso do bem-estar" humano.

A mutação social da "verdade", da verdade religiosa à verdade científica, a verdade posta em debate em que o verdadeiro de hoje é o erro de amanhã, gerou incerteza. As instituições seculares e seus clérigos "profanos" são menos capazes de enquadrar normativamente o Laos na busca de um progressofelicidade. De modo relativamente análogo às instituições religiosas do segundo patamar, essas instituições se veem desestabilizadas.

Uma individualização da relação com a religião já havia acontecido, do mesmo modo que também se instaura, no contexto dessa modernidade tardia, um processo de individualização em relação às instituições seculares. Estas, depois de terem obtido êxitos certos, passam então a ser afetadas pelo desenvolvimento dos novos questionamentos. Diversas estratégias tentam reduzir a incerteza: e algumas delas (dominantes) estão ligadas à comunicação de massa, aos novos clérigos midiáticos, e outras podem estar relacionadas de uma nova maneira com a religião (Baubérot, 2004, p. 205-223; 2007e, p. 112-118; 2008 a, p. 237-246).

Dito isso, veremos o essencial dos três indicadores de cada patamar ${ }^{16}$. Em primeiro lugar, no que tange à instituição, o primeiro patamar corresponde a uma diferenciação entre o espaço institucional global e o espaço institucional reconhecido à religião, a qual deixa de ser uma instituição simbolicamente englobante (all-encompassing). Isso contribui para a autonomização, para o desenvolvimento de instituições seculares que apresentam uma forte dimensão simbólica (escola, medicina...). O segundo patamar corresponde a uma espécie de dança cruzada entre a instituição religiosa, que perde certas características institucionais como a tendência à obrigação (ou a uma forte pressão) social, e as instituições seculares que assumem mais ou menos essas

\footnotetext{
${ }^{16}$ Como para todos os tipos ideais, nenhum patamar corresponde perfeitamente a uma realidade empírica. Cada situação concreta parece mais próxima ou mais distante de um dos patamares, podendo inclusive ter uma característica que a aproxima de um patamar e outra que corresponde mais à lógica de outro patamar. Por fim, a periodização não é obrigatoriamente idêntica em todos os países.
} 
características ${ }^{17}$. No terceiro patamar, o processo de desinstitucionalização atinge as instituições seculares (que tiveram seu apogeu no segundo patamar), e desenvolvem-se práticas ditas "consumistas", em que a "responsabilidade" pelas decisões tomadas se desloca socialmente da própria instituição para o indivíduo, levando este último a manter uma relação menos respeitosa e mais instrumental com as instituições.

Em seguida, no que diz respeito à legitimidade social ${ }^{18}$, no primeiro patamar, a religião mantém uma grande legitimidade como principal fonte de socialização da moral pública (o ateu é suspeito de ser "associal"). Com o segundo, a religião torna-se progressivamente "assunto privado", tornando socialmente facultativa a socialização que ela efetua e possibilitando que um indivíduo seja ateu sem ser socialmente considerado amoral. As instituições seculares tendem a assumir a socialização. No terceiro patamar, a socialização desvincula-se, pelo menos de modo relativo, dos suportes institucionais e adota uma lógica predominantemente mimética que tem como principal suporte a massificação e a globalização da comunicação.

Por fim, em matéria de pluralismo, no primeiro patamar, o pluralismo se estabelece, mas tende a limitar-se a certas religiões; o segundo patamar comporta uma noção mais extensiva do pluralismo religioso que abrange o agnosticismo e o ateísmo; o terceiro patamar corresponde a um duplo movimento de pluralismo fragmentado (que desestrutura as fronteiras entre o religioso e o não religioso) e de recomposição identitária em que o religioso pode ser considerado como recurso social, numa relação mais próxima ou mais distante dos princípios democráticos liberais forjados no primeiro patamar (Baubérot, 2007e, p. 48-50; 64-68; 112-115).

\section{Mudança social e modernidades}

Esta abordagem, moderada quanto ao uso de paradigmas, privilegia a construção de tipos ideais e periodizações de média duração. JPW, por sua vez, em sua abordagem, enquadra suas análises por diversos paradigmas (secularização, modernidade, ultramodernidade...). Apesar disso, existem convergências inegáveis que não surpreendem, pois nós dois percorremos uma longa trajetória de companheirismo intelectual e nossos trabalhos foram muitas vezes complementares. No entanto, faz alguns anos que tentamos emitir hipóteses mais abrangentes, o que torna as divergências mais visíveis e, ao mesmo tempo, enriquecedoras no âmbito de um debate mais amplo.

\footnotetext{
17 Obrigação de instrução, de certas vacinas, multiplicação de controles médicos, etc.

18 Aspecto privilegiado para analisar a inter-relação entre laicização e secularização.
} 
Em minha perspectiva, os dois primeiros patamares são acompanhados, tendencialmente, por uma "secularização-transferência" (primeiro, em processo, e depois, estabelecida ${ }^{19}$ ). Eu a estudei principalmente a partir da institucionalização da medicina, que correspondeu a um afastamento social do "outro mundo" (a esperança no além) para concentrar as questões sociais "neste mundo" (o prolongamento da expectativa de vida) (Baubérot, 2006b). No terceiro patamar e na modernidade tardia, a secularização é tendencialmente "desencantada" (Baubérot, 2004, p. 65-68; 2007 a, p. 114-116; 112-118). Existe, a priori, uma concordância com as teses de JPW. Porém, ele distingue duas modernidades, e não três períodos-tipos: a modernidade ("secularizante") e a ultramodernidade ("secularizada") (Willaime, 2007, p. 151).

É aí que nossas diferenças se concretizam. Para JPW, na modernidade, se, por um lado, as instituições sociais se emanciparam "das referências ou das tutelas religiosas, por outro, na verdade, elas se mantiveram muito tradicionais sob formas secularizadas". Ao contrário, segundo ele, "com a ultramodernidade, são as sacralizações seculares do trabalho, do político, da educação e da família que se veem afetadas" (Willaime, 2008, p. 19; 2006 a, p. $80 ; 2007$, p. 151). A meu ver, essa perspectiva focalizada na secularização minimiza de duas maneiras as mudanças propriamente institucionais que ocorreram nos dois primeiros períodos da modernidade ${ }^{20}$.

Em primeiro lugar, quanto à laicização, a mudança institucional foi totalmente estrutural. Ao inverso do que aponta JPW, a família nuclear não corresponde ao "modelo tradicional", trata-se de um novo modelo familiar, em conformidade com o primeiro patamar (Willaime, 2008, p. 24). Além disso, na sociedade tradicional, nem a escola nem a medicina possuíam verdadeiras características institucionais. As Luzes privilegiam "a educação doméstica" e mostram-se hostis ao ensino de massa. É na Revolução que, por um "corte epistemológico radical”, esboça-se tal projeto (Proust, 1990, p. 59, 62 et seq.). O século XIX o realiza progressivamente, e a institucionalização da escola (que teve a obrigação da instrução como um indicador essencial) favorece uma laicização moderada (neutralidade confessional) ou mais radical (neutralidade religiosa) em vários países (Baubérot, 2007e, p. 60-62)21. Por fim, os médicos quase não curavam mais que os "empíricos" quando foram promulgadas as leis

${ }_{19}$ No sentido anglo-americano do termo.

${ }^{20}$ A modernidade ascendente e a modernidade estabelecida.

${ }^{21}$ Willaime menciona "uma transferência do magistério educativo sob a tutela clerical para um magistério educativo sob a tutela estatal" (2007, p. 153; cf. 2008, p. 23), mas falar apenas de transferência diminui a importância da mudança político-institucional: não se trata mais, estruturalmente, da mesma "escola". 
sobre o exercício ilegal da medicina, elemento essencial para a construção de uma instituição médica poderosa e autônoma em relação à religião (Baubérot, 2006b) $)^{22}$.

Assim, a modernidade ascendente e seu resultado, a modernidade estabelecida, constituem uma ruptura muito maior com a "sociedade tradicional" do que pensa JPW. Elas comportam, de fato, "transferências", mas estão longe de se reduzirem a isso. O rigor de sua análise não está em discussão, porém, por um lado, a ausência de distinção entre secularização e laicização enquadra a análise exclusivamente no campo um pouco estreito da sociologia da religião e, por outro, sua abordagem enfoca acima de tudo o atual e tem o aspecto diacrônico como ponto de comparação, sem estudá-lo em si mesmo.

Nossas perspectivas também divergem quanto à abordagem da secularização em si. Se houve uma transferência de crenças $^{23}$ para as instituições seculares, a sacralidade dessas crenças mostrou-se estruturalmente diferente daquela da antiga religião globalizante. Por um lado, porque essas instituições, inserindo-se no processo de diferenciação institucional, não podiam aspirar à mesma globalidade. Por outro lado, se a religião reivindicava explicitamente uma dominação heterônoma, as instituições seculares, ao mesmo tempo em que desejavam exercer uma dominação análoga (nisso, houve "transferência"), afirmaram (na ótica das Luzes) promover a autonomia do indivíduo (Baubérot, 2006 c, p. 159 et seq.) $)^{24}$. Essas duas diferenças contribuíram para que perdessem sua plausibilidade no período da modernidade tardia (idem, 2006c, p. 160-163). Como Blumenberg (1988) (versus Carl Schmitt), penso que a dita secularização-transferência já gera um estado de crise dos processos de legitimação. Considero também que JPW avulta a mudança social (certamente importante) destas últimas décadas (que, no seu pensamento, corresponde à mudança de paradigma da modernidade para a ultramodernidade).

Essa perspectiva da ultramodernidade, como "fase de radicalização e de universalização das consequências da modernidade" (Willaime, 2008, p. 16)

\footnotetext{
${ }^{22}$ A autonomia em relação à religião pode variar conforme os períodos e os países.

${ }^{23}$ Segundo Giddens, a confiança é uma noção fundamental das instituições da modernidade. Para mim, isso implica acreditar na validade, no aspecto desejável do objetivo perseguido (saúde, instrução, cf. a salvação), acreditar que uma instituição constitui a única via para alcançar tal objetivo (medicina, escola, cf. a Igreja), acreditar que os agentes institucionais praticamente não cometem falhas profissionais (clérigos seculares, cf. clérigos religiosos). A secularização efetuou, de fato, nesses níveis, certa transferência de crenças, e a modernidade tardia constitui o momento histórico em que essas três crenças perdem plausibilidade em relação às instituições seculares ( $c f$. Baubérot, 2006c, p. 161 et seq.).

${ }^{24}$ Elas o fizeram parcialmente. Aliás, a instituição religiosa também o fez. Porém, a diferença de discurso não é desprovida de consequências.
} 
lembra um pouco, implicitamente, aquela do "fim da história". Para JPW, as sociedades nacionais "regularam de certa forma, cada uma a seu modo, as relações Estado-religiões" (idem, 2008, p. 14). Mas, não, nada está "regulado", pois a mudança social continua. Emprego a expressão "modernidade tardia" 25 para indicar que, se não saímos da modernidade (recusa em comum com JPW da noção de "pós-modernidade"), é possível que estejamos passando progressivamente para outro marco sócio-histórico.

\section{Esfera pública, espaço público, esfera privada}

Essas diferenças remetem a outra abordagem do público e do privado. Para JPW, a laicidade francesa tendeu a "confinar" a religião na "esfera privada" (Willaime, 2008: 83). Na ultramodernidade ${ }^{26}$, essa limitação do papel da religião deve ser ultrapassada, e, apesar de seus "erros incontestáveis e de sua falta de jeito"27, Nicolas Sarkozy recebe o mérito de tê-lo compreendido. Minha discordância diz respeito a vários aspectos. Além do fato de que o movimento de privatização da religião está longe de ser exclusivamente "francês", o verbo "confinar" é depreciativo. Ora, a construção epistemológica da distinção público-privado corresponde à valorização da liberdade do indivíduo. Locke, que tende a situar a religião no privado, é o teórico do "governo limitado" e não somente da separação entre religião e Estado.

Para Benjamin Constant, a "felicidade" está na dita esfera privada. Neste caso, então, são principalmente as classes superiores que dela gozam. Quando você está "confinado" numa aldeia ou num bairro, sendo objeto do olhar vigilante de outrem, sem mobilidade geográfica ou social, sem saber ler nem escrever, sua esfera privada é restrita. Esta é menos restrita se, sabendo ler e escrever e graças às ferrovias, você puder ir para um lugar onde, anonimamente, compra uma brochura anarquista ou licenciosa (autorizada por novas leis liberais) e se puder também conceber um futuro diferente daquele de seus pais. É somente a partir da segunda metade do século XIX que ocorre uma democratização da esfera privada. Ela contribui para o desenvolvimento da individualidade, de uma liberdade-responsabilidade do indivíduo, típica da "sociedade ideal" (no sentido de Durkheim) da modernidade (Baubérot, 2006c,

\footnotetext{
${ }_{25}$ Por analogia com a expressão "Antiguidade tardia" ou "Idade Média tardia". Convém lembrar que isso não implica nenhuma "decadência".

26 Este exemplo, assim como outros, mostra um emprego ambivalente do termo "ultramodernidade" em Willaime: é explicitamente um paradigma, mas, implicitamente, corresponde a uma periodização.

27 Sem avaliar as consequências da presença desses erros no discurso presidencial (Willaime, 2008 , p. 80 et seq.). Ora, essas declarações contribuem para estruturar esse discurso.
} 
p. 156 et seq.). É no mesmo momento histórico que se desenrola o processo de privatização da religião. Para esta, talvez não seja um tão mau negócio.

Além disso, as leis liberais sobre as liberdades (colportagem, imprensa, reunião, associação e liberdade de consciência) fazem surgir progressivamente uma nova representação da sociedade civil, diferente daquela que prevaleceu desde Aristóteles até a filosofia política de Hobbes ou de Rousseau. A sociedade civil deixa de ser concebida no âmbito da unidade da sociedade política ${ }^{28} \mathrm{e}$ passa a ser progressivamente percebida como autônoma em relação ao Estado. Isso gera uma representação ternária que comporta um espaço público ${ }^{29}$ da sociedade civil, diferente tanto da esfera pública, política e institucional quanto da esfera privada.

Com certeza, JPW não o ignora. Ele menciona esse espaço como "aquele dos corpos intermediários constituídos pelos múltiplos e diversos movimentos, grupos e associações que contribuem para a vida social". Porém, na verdade, ele tende a confundir as duas noções da sociedade civil, incluindo aí as “instituições públicas” (Willaime, 2008, p. 83). Consequentemente, seu livro às vezes unifica espaço público e esfera pública, o que o faz crer que proponho "a total privatização do religioso" (idem, 2008, p. 86). Ora, mesmo na França, com a lei de separação (1905), a religião está presente nesse espaço público autônomo. Anteriormente, no primeiro patamar, os cultos reconhecidos ainda tendiam a formar um "corpo intermediário" mais ou menos incorporado ao Estado. Em 1905, as restrições à liberdade de assembleias e de discurso público das autoridades religiosas que existiam até então foram eliminadas (Baubérot, 2004, p. 97 et seq.). Não é mais necessário pregar o "advento de uma laicidade positiva" (Nicolas Sarkozy) para isso.

Do meu ponto de vista, esse espaço público autônomo funciona socialmente com uma dominante ideal tipicamente associativa (voluntária e livre), não tendo, na verdade, nada de redutor: os inúmeros debates sociológicos destas últimas décadas sobre o "capital social" das ONGs mostram o peso que certas estruturas associativas ${ }^{30}$ podem adquirir. Em contrapartida, os organismos cujo funcionamento social é institucional e tem um aspecto de obrigação social pertencem à esfera pública. Um exemplo simples: na França,

${ }_{28}$ Representação dominante, embora, empiricamente, as situações sejam mais complexas.

29 Esse espaço não é somente geográfico (como a rua, por exemplo), mas também um espaço social estruturado de maneira associativa.

${ }^{30}$ Por um lado, o fato de que uma religião mantenha socialmente traços institucionais significa uma laicização menos acentuada; por outro, mesmo que a separação esteja ligada à estrutura associativa da organização religiosa, isso não impede que essa organização possa funcionar internamente como uma instituição (cf. o direito canônico na Igreja Católica), tampouco que mantenha certas relações com o Estado. 
praticar o proselitismo em praça pública é permitido. Na escola, no hospital, isso é proibido, assim como numa prefeitura. O Conseil d'État ${ }^{31^{*}}$ acatou essa distinção, em 1989, permitindo que os estudantes portassem símbolos religiosos discretos dentro da escola e proibindo o uso desses símbolos caso se tornassem proselitistas. A lei de 2004, por sua vez, a partir de uma concepção da escola como "santuário republicano" (J. Chirac) $)^{32}$, alega que tais símbolos seriam ipso facto proselitistas na escola, ao passo que são permitidos no hospital, no tribunal e na prefeitura, para aqueles que não exercem papel institucional, embora o proselitismo seja proibido nesses mesmos locais. Por essa razão, como membro da Comissão Stasi, eu não votei a favor dessa proposta ${ }^{33}$.

O desenvolvimento sócio-histórico de um espaço público autônomo mostra que as representações do "privado" e do "público" não podem ser diacronicamente estáticas. A privatização da religião permitiu em seu tempo, instaurar a liberdade de pertencimento religioso. $\mathrm{Na}$ época atual, acentuase nas diferentes sociedades modernas ${ }^{34}$ uma desconexão entre a crença individual e a religião como organização coletiva. A liberdade religiosa é, de maneira mais ou menos nítida, não somente a liberdade de pertencimento, mas também a liberdade do indivíduo de manter, perante a religião, uma relação de proximidade ou de distância. É o direito de ser heterodoxo de mil maneiras (desde a "virtuosidade religiosa", à maneira de Max Weber, até os fenômenos de do it yourself... $)^{35}$. A problemática, principalmente em matéria de costumes, é muito atual no nível internacional, em que católicos praticantes desejam poder recorrer à contracepção, ao aborto, ter seu direito reconhecido de "morrer com dignidade" (eutanásia).

Não se deveria, por conseguinte, modificar a perspectiva sociológica e considerar a hipótese de que a crença se situa na esfera privada e que a religião, na acepção organizacional do termo, constitui antes, com outras famílias de crenças $^{36}$ e outras culturas ${ }^{37}$, uma parte do espaço público da sociedade civil,

${ }^{31}$ N.T.: Na França, é o órgão mais elevado da ordem administrativa , possuindo atribuições jurisdicionais e administrativas. Em matéria administrativa, sua principal atribuição é emitir pareceres sobre as questões que lhe são submetidas pelo Governo.

32 Isso parece seguir uma perspectiva de religião civil.

${ }^{33}$ A respeito dessa comissão, $c f$. Baubérot, 2006d, e também uma comparação com a comissão quebequense, Bouchard-Taylor, in Baubérot, 2008b.

34 Para Willaime, essa individualização do religioso pode permitir uma cooperação entre Estados e religiões sem clericalismo. Sem dúvida, mas, ao contrário, ela pode também levar o Estado a não valorizar a importância das posições oficiais das religiões.

${ }^{35}$ É o que a razoável conciliação canadense leva em conta: M. Milot, 2002, p. 133 et seq.

${ }^{36}$ Mais estruturada em certos países - como a Bélgica - do que na França (cf. principalmente Grollet, 2005).

${ }^{37}$ Cf. Lazar, 2003, segundo o qual existem "fatos de cultura" (incluindo os fatos religiosos) numa situação em que as culturas se tornam cada vez mais dispersas. 
com suas tensões e suas problemáticas? Parece-me importante para a sociologia desenvolver essa nova percepção de que a laicidade "foge assim do domínio exclusivo das relações com os cultos". Ela implica tanto a autonomia da esfera pública quanto a da esfera privada (e dos costumes) perante as religiões (ou outros clericatos seculares) no âmbito de uma regulação laica ${ }^{38}$. Será que se trata verdadeiramente, como afirma JPW, de uma "laicidade de desconfiança" $(2008$, p. 83,94$)$ ?

Por fim, a oposição binária entre público e privado que JPW faz às vezes mistura espaço público e esfera pública ${ }^{39}$. Essa confusão torna equivocada sua perspectiva de "volta da religião à esfera pública". Por certo, ele não deseja voltar ao "processo de autonomização do político e do religioso", mas logo fala "das relações entre esses dois poderes" (Willaime, 2008, p. 14). Ora, nas sociedades laicas, se o político pertence à ordem do poder que pode exercer, como mostrou Weber, uma coerção física e impor obrigações, a religião e, de modo geral, as famílias de pensamento pertencem à ordem da autoridade, isto é, à ordem da interiorização "voluntária" das normas. Na Idade Média cristã, já havia a distinção entre "espiritual" e "temporal", mas o primeiro obtinha do segundo o uso da coerção física. A laicização põe fim nessa situação. JPW concorda com isso. No entanto, falar de dois "poderes" é correr o risco de desconsiderar pressões possíveis da potestade pública em proveito desta ou daquela religião.

\section{A religião civil}

Na religião civil, também existem convergências e divergências. Eu compartilho da ideia de que as sociedades podem sentir "necessidade de referir sua existência a um imaginário que lhes permita representar sua fundação e criar a memória de sua história através de diversos símbolos e ritos" por meio dos quais "glorificam sua unidade", pois "são construções históricas inevitavelmente volúveis e precárias". Logo, pode-se designar pelo conceito de religião civil "o sistema de crenças e de ritos através do qual uma sociedade sacraliza seu estar-junto e mantém uma devoção a si mesma" (Willaime, 2008, p. 89).

\footnotetext{
${ }^{38}$ É o que a lei Weil, sobre o aborto (1975), faz de três maneiras: primeiramente, dissociando a lei das normas religiosas, depois, admitindo uma objeção de consciência possível dos profissionais da saúde perante a lei, e, por fim, deixando a decisão final do aborto ao encargo da mulher, e não ao encargo do agente institucional médico.

39 Desde a introdução, constata-se esse deslize: "Entre a setorização comunitária das identidades religiosas e um espaço público que só seria universal por abstenção das identidades, há lugar para um reconhecimento cidadão e laico das religiões na esfera pública" (2008, p. 9).
} 
Todavia, essa "necessidade" depende de parâmetros sociais, e convém avaliar a presença maior ou menor de elementos que induzem essa "sacralização". Neste sentido, o conceito de religião civil funciona no encontro do campo sociocultural da secularização com o campo sociopolítico da laicização. No contexto de uma secularização... secularizada, a construção de uma religião civil estruturada tenta (re)colocar o político numa posição elevada em que um "sistema [cultural] de crenças e ritos" permite assumir certa figura da totalidade. Mas será que o "estar-junto" abrange toda a coletividade política ou privilegia sua (ou suas) comunidade(s) cultural(ais) dominante(s)? Deverse-ia analisar, nesta perspectiva, diversos avatares da religião civil americana. $\mathrm{Na}$ França, as tentativas de religião civil opuseram durante muito tempo a França católica e a França republicana, com duas narrativas fundadoras (Baubérot, 2004, p. 260-264; 168-175), e, na Terceira República, a necessidade de uma religião civil é uma questão que está no seio do partido republicano ${ }^{40}$. JPW nos indica que, hoje, uma religião civil à francesa integra aspectos das duas Franças. Ele não percebe que não é por acaso que essa aproximação acontece justamente no momento em que a França se torna uma sociedade pluricultural.

A "construção histórica inevitavelmente volúvel e precária" das sociedades não leva obrigatoriamente à mesma "necessidade" de religião civil quando o político pode parecer portador de um projeto dinâmico de projeção no futuro e num contexto em que se sente uma grande incerteza. JPW insiste na importância do "culto das origens" na religião civil. A pane do projeto de futuro pode induzir uma estratégia de retraimento identitário. Esta é uma das razões da problemática sociopolítica de uma referência a uma herança religiosa em textos europeus de ordem jurídica e constitucional, ao passo que, em $1950^{41}$, não se sentia essa "necessidade"42. A referência recorrente do presidente Sarkozy à necessidade de "valorizar raízes essencialmente cristãs" da França segue o mesmo sentido ${ }^{43}$. Sem dúvida, essa conduta não deixa de

${ }^{40}$ Cf. Ihl (1996), que mostra a oposição de J. Ferry às tentativas de religião civil, o que Willaime acredita ser uma simples opinião minha (2008, p. 87).

${ }^{41}$ Havia partidos democratas cristãos poderosos, mas a Convenção Europeia dos Direitos do Homem, de 1950, não abriu espaço (como a Carta de Nice, em 2000) para debates sobre a obrigação de uma referência a uma herança religiosa.

${ }^{42}$ Essa referência a uma herança religiosa representa uma problemática política em vários países europeus, principalmente naqueles que, por sua história (Polônia, antigas nações do Império Otomano), possuem uma concepção mais comunitária do que individual da liberdade de religião. É, portanto, o contrário de uma posição franco-francesa fazer a análise crítica disso.

${ }^{43}$ Foi isso que critiquei em minha obra (Baubérot, 2008a), levando rigorosamente em conta - ao contrário de uma surpreendente asserção de JPW - as condições de enunciação (idem, 2008 a, p. 146-150). 
estar relacionada com a conjuntura da modernidade tardia (Baubérot, 2008 a, p. 236 et seq.), mas essa constatação não deve nos impedir de analisar as questões políticas subjacentes. Na verdade, quando digo que "a identidade moral" da França não tem uma dimensão religiosa maior do que a ateia ou a antirreligiosa $^{44}$, não se trata das diversas culturas que a formaram, e sim de sua identidade política, o que constitui uma aquisição da lei de separação de 1905. A lógica dessa lei consiste em estabelecer uma distância equivalente entre a esfera política e as diversas "famílias de pensamento" da sociedade civil $^{45}$, rompendo assim com os projetos anteriores. A lei o faz renunciando ao "culto das origens" revolucionárias (Baubérot, 2006 a, p.168-172) e afastandose de uma autocelebração da França, uma vez que não teme empréstimos determinantes tomados de laicidades de outros países (Baubérot, 2007c e 2007d).

De um ponto de vista ideal-típico, os elementos constitutivos da religião civil devem, portanto, ser distinguidos dos elementos de laicidade. Esta última implica uma separação entre a diversidade dos atores da sociedade civil e a unidade do corpo político com um objetivo de arbitragem, e não de se pôr acima. Empiricamente, contudo, na história de diferentes países, elementos de laicidade e elementos de religião civil estiveram presentes em maior ou menor medida, em conexão ou em tensão, gerando diferentes casos. Afirmar que não se pode "isentar" da religião civil por se tratar de um "fenômeno social" (Willaime, 2008, p. 87 et seq.) parece essencialista e constitui um modo curioso de negar o aporte da sociologia do ator. Tanto o grau de religião civil quanto o grau de laicidade (e suas respectivas formas) constituem, nos diferentes países, uma questão política, também ligada a regimes diferentes em sua historicidade: a religião civil é quase inexistente no Canadá, ao passo que nos EUA...

Durkheim (a quem Willaime se refere, 2008, p. 89 et seq.) puxa a laicidade para o lado da religião civil (Bellah, 1973) e parafraseia o capítulo de Rousseau em seu tratado sobre o Contrato Social (Durkheim, 2007 a, p. 97-99). No entanto, paradoxalmente, podemos estabelecer uma distinção conceitual entre religião civil e laicidade, referindo-as a dois conceitos durkheimnianos: a primeira, ao conceito de "integração" e a segunda, ao de "regulação" (Durkheim, 2007b).

\footnotetext{
44 Baubérot, 2008a, 86 (é por isso que Willaime me critica, 2008, p. 98).

45 Naquela época, a Igreja Católica, o livre pensamento, as minorias judias e protestantes.
} 


\section{A "teoria prática"}

As questões em jogo no debate são, portanto, teóricas, o que permite varrer a curiosa alegação de uma abordagem franco-francesa. Na verdade, nos 36 países onde ministrei aulas e conferências sobre a laicidade ${ }^{46}$, minha reputação está mais ligada ao fato de eu ter sido o primeiro (não o único) a internacionalizar essa noção. Já em 1994, a Equipe de História e Sociologia da Laicidade (que criei na École Pratique des Hautes Études - EPHE) coorganizou um simpósio sobre "laicidades" [no plural] e publicou uma obra sobre a laicidade na Europa (Dierkens, 1994; Baubérot, 1994). Em seguida, dei ênfase a esse aspecto e redigi, em 2007, uma obra intitulada Les laïcités dans le monde (Baubérot, 2007e). Universidades japonesas, por exemplo, convidaram-me dezenove vezes para debater sobre diferentes processos de laicização e de secularização. Micheline Milot, Roberto Blancarte e eu fomos os principais redatores da Declaração universal sobre a laicidade no século $X X I$, assinada em 2005 por 250 professores universitários de trinta países ${ }^{47}$.

$\mathrm{Na}$ verdade, essa alegação provém de uma confusão com o direito de intervir, por uma "parcialidade assumida" ${ }^{\text {, }}$, no debate político francês, aplicando aquilo que Durkheim designava como "teoria prática". Sem dúvida, este talvez não tenha percebido a tensão presente nessa forma de discurso entre saber e engajamento. Façamos então uma complementação de Durkheim com Weber, que defendeu a nomeação, para uma cátedra de jurista, de um anarquista que negava a validade do direito. Para o teórico da "neutralidade axiológica", essa "convicção" muito crítica apresentava um interesse heurístico, pois podia revelar um impensado (Weber, 1965, p. 411 et seq.). Um exemplo pode ilustrar essa posição: a problemática do gênero foi conduzida por uma militância feminista, antes de dar origem a análises de

\footnotetext{
${ }^{46}$ Para descartar essa asserção, ressalto que, desde 1991 (criação da cátedra "História e sociologia da laicidade" na EPHE), tenho ministrado aulas e/ou conferências sobre a laicidade nos seguintes países: Alemanha, Argentina, Áustria, Azerbaijão, Bélgica, Brasil, Bulgária, Canadá, Chile, Croácia, Dinamarca, Eslováquia, Espanha, Estados Unidos, Holanda, Hungria, Índia, Irlanda, Itália, Japão, Quirguistão, Líbano, Marrocos, México, Noruega, Peru, Polônia, Reino Unido, Romênia, Rússia, Suécia, Suíça, Ucrânia, Turquia, Tunísia, Vaticano, Vietnam. São 36 países (em 17 deles realizei várias missões), onde a relação com a laicização é muito diferente e onde sempre obtive informações e mantive diálogos universitários sobre a situação nacional de cada um. 36 países? Não, esqueci o $37^{\circ}$ : a França!

47 Esse texto contém 18 Artigos (citado especialmente em Baubérot, 2006 a, p. 251-257). Willaime (2008, p. 76) contesta um elemento frasal do Artigo 14, que propõe "desvincular o religioso das evidências sociais". O início e o fim do Artigo mostram que se trata de "processos de laicização" diante de religiões como "sistemas de dominação social" da ordem de uma "imposição política".

${ }^{48}$ Para falar do mesmo modo como ele apresenta sua própria obra (Willaime, 2008, p.7).
} 
ciências sociais. Além disso, tanto JPW quanto eu, nós não fugimos de um papel misto de especialista. Quanto a mim, nesta situação, defendo uma concepção dialética da laicidade, mantendo a mesma distância de um neorrepublicanismo que, sob o manto da laicidade, tenta impor aos "crentes" uma secularização interna e de um neoclericalismo, em que se acredita, com menos laicidade, melhor responder aos desafios da secularização (Baubérot, 2008 a, p. 228 et seq.). O contexto francês tem me levado, desde 1989, a me separar muito dos neorrepublicanos, tomando ainda mais distância de uma representação da laicidade cuja narrativa sócio-histórica é equivocada e que, ao contrário do que escreve Willaime, vai estruturalmente muito além do "reconhecimento" de uma "contribuição" de "famílias espirituais" à "República laica", proclamando a superioridade do cristianismo (Latrão) e/ou da crença em Deus em relação às outras Weltanschauung (Riad) (Willaime, 2008, p. 82) ${ }^{49}$. Depois do discurso de Latrão, certos bispos franceses temiam que, "passando por cima deles", negociações fossem iniciadas entre o Vaticano e o Palácio do Eliseu para uma nova Concordata ${ }^{50}$. E podemos dizer que até mesmo a ampla definição do secularism proposta por Charles Taylor é transgredida por esses discursos, uma vez que tal definição insiste no fato de que o Estado não deve favorecer nenhum ponto de vista religioso ou irreligioso ${ }^{51}$.

Eu poderia prolongar este interessante debate, mas preciso concluir com brevidade. Jean-Paul Willaime reivindica a "pesquisa internacional" (Willaime, 2008, p. 87). Eu também me insiro nela, assumindo ao mesmo tempo, por vezes, uma posição de franco-atirador. A conduta científica, por definição, se mantém sempre em movimento. Por nossa conta e risco podemos nos aventurar!

\section{Referências}

BAUBÉROT, Jean (éd.). Religions et laïcité dans l'Europe des Douze. Paris: Syros, 1994.

Laïcité 1905-2005, entre passion et raison. Paris: Seuil, 2004.

L'intégrisme républicain contre la laïcité. La Tour d'Aigues: 1'Aube, 2006a.

La laïcisation de la médecine. In: WIEVIORKA, M. Disposer de la vie, disposer de la mort. La Tour d'Aigues: l'Aube, 2006b. p. 25-40.

\footnotetext{
${ }^{49}$ Não desenvolvo esse ponto, pois pode ser encontrado em meu livro (Baubérot, 2008a). A forma humorística com que às vezes me expresso ofendeu JPW e o impediu de perceber que é um modo (pedagógico) de vulgarizar, para um grande público, saberes sócio-históricos ou mesmo debates filosóficos.

${ }^{50}$ É o testemunho de um dos bispos.

${ }^{51}$ Taylor in Levey-Modood, 2009, xii.
} 
BAUBÉROT, Jean. Modernité tardive, religion et mutation du public et du privé. Social Compass, v. 53, n. 2, p. 155-168, 2006c.

. Le dernier des Curiace. Un sociologue dans la Commission Stasi. In: CÔTÉ, P.; GUNN, J. (éds.). La nouvelle question religieuse. Régulation ou ingérence de l'État. Bern: Peter Lang, 2006d. p. 247-272.

. Histoire de la laïcité en France. 4. éd. Paris: PUF, 2007a.

La construccion sociológica de la laicidad en objecto de estudio. In: DA

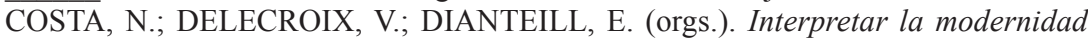
religiosa. Montevideo: CLAEH, 2007b. p. 11-22.

. Cultural transfert and national identity in french laicity. Diogenes, 552, p. 17-25, 2007c; Transferts culturels et identité nationale dans la laïcité française. Diogène, 218, avril-juin, p. 18-27, 2007c.

. La représentation de la laïcité comme "exception française". Cosmopolitiques, v. 16 , p. $119-132,2007 \mathrm{~d}$

. Les laïcités dans le monde. Paris: PUF, 2007e.

. La laïcité expliquée à M. Sarkozy et à ceux qui écrivent ses discours. Paris: Albin Michel, 2008a.

Une laïcité interculturelle. Le Québec avenir de la France? La Tour d'Aigues: l'Aube, 2008b.

BAUBÉROT, Jean; MATHIEU, Séverine. Religion, modernité et culture au RoyaumeUni et en France (1800-1914). Paris: Seuil, 2002.

BELLAH, Robert. Emile Durkheim on morality and society. Selected Writings. Chicago: University of Chicago Press, 1973.

BLUMENBERG, Hans. La légitimité des temps modernes. Paris: Gallimard, 1988.

BRUCE, Steve. God is Dead. Secularization in the West. Oxford: Blackwell Publishing, 2002.

CASANOVA, Jose. Public religion in the modern world. Chicago: The University of Chicago Press, 1994.

COURBAGE, Youssef; TODD, Emmanuel. Le rendez-vous des civilisations. Paris: Seuil, 2007.

DIERKENS, Alain. Pluralisme religieux et laïcités dans l'Union européenne. Bruxelles: Éditions de l’Université Libre de Bruxelles, 1994.

DOBBELAERE, Karel. Secularization: a multi-dimentional concept. London: Sage Publication, 1981.

. De la sécularisation. Revue théologique de Louvain, v. 39, p. 177-196, 2008.

DURKHEIM, Émile. Le Contrat Social de Rousseau. Paris: L'Harmattan, 2007a.

. Le suicide. Paris: Presses Universitaires de France, 2007b.

GROLLET, Philippe. Lä̈cité: utopie et nécessité. Bruxelles: Labor, 2005.

IHL, Olivier. La fête républicaine. Paris: Gallimard, 1996. 
LAZAR, Philippe. Autrement dit laïque. Paris: Liana Levi, 2003.

MARTIN, David. A General Theory of Secularization. Oxford: Blackwell, 1978.

MILOT, Micheline. Laïcité dans le nouveau monde. Le cas du Québec. Turnhout: Brepols, 2002.

PROUST, J. Que signifiait pour les encyclopédistes la sécularisation de l'enseignement? In: BOST, H. Genèse et enjeux de la laïcité. Genève: Labor et Fides, 1990. p. 59-71.

SHAKMAN, Hurd Elizabeth. The politics of secularism in international relations. Princeton: Princeton University Press, 2008.

WEBER, Max. Essais sur la théorie de la science. Paris: Plon, 1965.

WILLAIME, Jean-Paul. Europe et religions, les enjeux du XXI siècle. Paris: Fayard, 2004.

. Religion in ultramodernity. In: BECKFORD, J; WALLIS, J. (eds.). Theorising Religion: Classical and Contemporary Debates. Aldershot: Ashgate, 2006a. p. 73-85.

. La sécularisation: une exception européenne? Revue Française de Sociologie, v. 47, n. 4, p. 755-783, 2006 b.

. Reconfigurations ultramodernes. Esprit, mars-avril, p. 146-155, 2007.

. Le retour du religieux dans la sphère publique. Vers une laïcité de reconnaissance et de dialogue. Lyon: Olivétan, 2008. 